\title{
PEMBELAJARAN BAHASA INGGRIS DI PERGURUAN TINGGI ISLAM DALAM KONTEKS ESP (ENGLISH FOR SPESIFIC PURPOSE)
}

\author{
Wardah
}

\begin{abstract}
Abstrak
Secara singkat, tulisan ini membahas tentang pembelajaran bahasa inggris untuk mahasiswa Pendidikan formal yang memberikan pengajaran bahasa asing salah satunya adalah perguruan tinggi islam. Pada perguruan tinggi islam, bahasa asing menjadi salah

satu mata kuliah yang harus diambil oleh mahasiswa. Bahasa asing tersebut adalah

bahasa inggris. Bidang pengajaran bahasa Inggris dengan tujuan tertentu atau lebih

dikenal dengan English for Specific Purpose (ESP) merupakan bidang pengajaran bahasa Inggris yang tergolong baru dengan menyesuaikan jurusan keilmuan di perguruan

tinggi. Dengan pengajaran bahasa inggris di perguruan tinggi islam, diharapkan

mahasiswa mampu mengkaji keilmuan islam dalam bahasa asing khususnya bahasa inggris dan mampu mengikuti perkembangan globalisasi dunia yang menuntut seseorang dapat menguasai bahasa asing.
\end{abstract}

Kata kunci: bahasa inggris, ESP, perguruan tinggi islam

\section{A. Pendahuluan}

Pendidikan Islam adalah suatu proses penanaman nilai- nilai Islam melalui pengajaran, bimbingan dan latihan yang dilakukan dengan saddar dan penuh tanggung jawab dalam rangka pembentukan, pembinaan, pendayagunaan, pengembangan pikir, zikir, dan kreasi manusia sehingga terbentuk pribadi muslim sejati yang mampu mengembangkan kehidupannya dengan penuh tanggung jawab dalam rangka beribadah kepada Allah SWT untuk mencapai kebahagiaan hidup di dunia dan akhirat. Pendidikan Islam di Indonesia telah berlangsung sejak masuknya Islam ke Indonesia. Proses masuknya islam tidak lepas dari peran bahasa sebagai alat komunikasi manusia dalam kehidupan sehari- hari. Dengan bahasa, seseorang bisa menyampaikan ide, pikiran, perasaan atau informasi kepada orang lain baik secara lisan maupun tulisan. Hal ini sesuai dengan persepsi dan pemikiran bahwa bahasa adalah alat komunikasi antar anggota 
masyarakat berupa symbol bunyi yang dihasilkan oleh alat ucap manusia dan merupakan hal terpenting dalam kehidupan sesorang, karena bahasa adalah termasuk kebutuhan manusia dalam berhubungan dengan sesamanya. Maka semakin tinggi tingkat penguasaan bahasa seseorang, semakin baik pula penggunaan bahasa dalam berkomunikasi.

Sebagai alat komunikasi, bahasa harus dikuasai dengan baik agar dapat berkomunikasi dengan orang lain dengan baik. Penguasaan bahasa yang baik merupakan hal yang diupayakan dan dipelajari, apalagi bahasa yang dipelajari adalah bahasa asing. Berdasarkan pendapat Mulijanto Sumardi (1974:56), bahwa apapun tujuan yang ingin dicapai oleh seseorang yang mempelajari bahasa asing, tujuan akhirnya ialah agar ia dapat menggunakan bahasa tersebut baik lisan maupun tulisan dengan tepat, fasih, dan bebas untuk berkomunikasi dengan orang yang menggunakan bahasa tersebut. Karena tuntutan akan kemampuan berbahasa asing semakin meningkat, seiring dengan kemajuan ilmu pengetahuan, teknologi, informasi, dan bidang- bidang lainnya. Seseorang dapat lebih leluasa menjalin komunikasi dengan orang lain yang berasal dari bangsa yang berbeda dengan dirinya jika memiliki kemampuan berbahasa asing yang baik. Dengan kondisi tersebut, maka mempelajari bahasa asing sangat bermanfaat pada pemahaman antar pribadi, kelompok, maupun bangsa.

Pendidikan formal yang memberikan pengajaran bahasa asing salah satunya adalah perguruan tinggi islam. Pada perguruan tinggi islam, bahasa asing menjadi salah satu mata kuliah yang harus diambil oleh mahasiswa. Bahasa asing tersebut adalah bahasa inggris. Bahasa inggris sebagai bahasa asing yang global dan universal di dunia. Mempelajari bahasa asing adalah salah satu langkah awal yang baik untuk dapat berkomunikasi dengan orang lain dalam lingkup internasional. Bahasa Inggris menjadi global lingua franca (bahasa penghubung) utama karena dua hal, yaitu geografis-sejarah dan sosialbudaya.3 Bahasa Inggris, diguna sebarkan dalam dunia global melalui migrasi orang-orang yang berbahasa Inggris, penjajahan oleh orang Inggris, peran dan pengaruh Amerika dalam skala global, komunikasi internasional, media, film, teknologi, dan lain-lain. Selain itu, bahasa Inggris menjadi bahasa utama dalam perdagangan, diplomasi, dan juga pendidikan di dunia.

Pada zaman mutakhir seperti sekarang ini, banyak penelitian dan 
sumber-sumber ilmu pengetahuan yang ditulis dan dipresentasikan dalam Bahasa Inggris. Sehingga, menguasai Bahasa Inggris dapat menjadi salah satu pintu untuk menguasai pengetahuanpengetahuan mutakhir. Sejak periode 1750-1900, ilmu pengetahuan dan teknologi telah banyak ditulis menggunakan Bahasa Inggris. Ini mempengaruhi pengguna sumbersumber dalam Bahasa Inggris seperti para akademisi dan mahasiswa. Sumber sumber ilmu pengetahuan yang ditulis dalam Bahasa Inggris dapat berupa buku, artikel, maupun jurnal. Hal ini menuntut mereka untuk bisa berbahasa Inggris secara tulisan maupun lisan. Seorang akademisi atau mahasiswa akan diakui karya-karyanya secara luas bila mereka bisa menciptakan suatu terobosan yang bermanfaat bagi dunia yang biasanya ditulis atau dipresentasikan kepada masyarakat dunia menggunakan bahasa global, yakni Bahasa Inggris.

Bahasa Inggris digunakan tidak terbatas pada semua sektor, ini karena Bahasa Inggris sebagai penunjang sarana komunikasi seluruh warga dunia tentang berbagai lini. Dalam dunia pendidikan, Bahasa Inggris adalah bahasa pengantar dalam lingkup ilmu multidisipliner. Penggunaan Bahasa Inggris dalam bidang ilmu multidisipliner ini melahirkan English for Specific Purpose (ESP) yang berfokus pada pemerolehan keahlian profesional yang terintegerasi dengan beragam kecakapan, disipliner, dan praktek. Misalnya, Bahasa Inggris dalam dunia Pendidikan, Kesehatan, Ekonomi, Hukum, Agama, dan lain-lain. ESP bertujuan untuk mempermudah komunikasi antar pelaku suatu bidang tertentu. Sehingga, pembelajaran ESP dalam dunia akademik sangat dianjurkan untuk digalakkan, mengingat setiap bidang selalu mengalami perkembangannya sendiri termasuk pendidikan yang berlatarbelakang keislaman.

\section{B. Bahasa Inggris di Perguruan Tinggi Islam}

Di dalam dunia pendidikan, termasuk pendidikan Islam. bahasa inggris mempunyai peran yang sangat penting, karena dengan bahasa inggris, dapat diibaratkan sebagai kunci untuk menguasai ilmu pengetahuan. kita dapat mempelajari ilmu pengetahuan yang menggunakan bahasa pengantar bahasa inggris. Sebagaimana yang kita ketahui, beberapa referensi pendidikan Islam menggunakan bahasa pengantar bahasa Arab, misalnya buku tentang kedokteran milik Ibnu Sina, tentang Matematika milik Al Jabar, tentang politik dan sejarah milik 
Ibnu Khaldun. Buku-buku mereka saat ini diajarkan di negara-negara barat misalnya di Jerman, Inggris, Canada, ataupun Amerika. Sehingga buku-buku mereka yang berbahasa Arab itu telah diadopsi dan diterjemahkan dalam bahasa Inggris.

Dengan menguasai bahasa Inggris, kita juga dapat bertukar informasi tentang Islam, ilmu pengetahuan, ataupun keduanya yang lebih dikenal dengan Sains Islam. Dan juga kita dapat berdakwah dengan menggunakan tulisan-tulisan seperti artikel ataupun menyusun buku dalam bahasa Inggris berisikan kajian Islam, kemudian kita publikasikan ke dalam internet. Seperti yang kita tahu bahwa media internet sangat efektif sebagai alat penyebar informasi. Dan bahasa inggris adalah bahasa yang sering digunakan dalam internet. Maka dapat dipahami bahwa bahasa Inggris sangat penting dalam dunia pendidikan Islam.

Sebagai bahasa universal, bahasa Inggris dalam dunia pendidikan Islam adalah termasuk sebuah media komunikasi untuk berdakwah ke seluruh dunia terutama dunia Barat seperti Amerika dan Eropa. Kita tetap mempelajari Islam dengan menggunakan bahasa aslinya yaitu bahasa Arab, setelah itu kita dapat menyebarkan ke orang - orang non- muslim. Selain itu, alasan lain kenapa bahasa Inggris juga sangat penting adalah karena bahasa ini juga bisa digunakan sebagai media untuk menyelesaikan kesalah pahaman, misalnya bila terdapat seseorang atau beberapa orang non muslim Barat yang mengalami kesalahpahaman dalam mempelajari agama Islam, dan mereka tidak ataupun kurang mampu memahaminya, kita dapat membantu mereka dengan memberikan penjelasan tentang Islam dengan menggunakan bahasa Inggris. Dalam dunia pendidikan, masih terjadi beberapa hambatan dalam mengajarkan bahasa Inggris terutama dalam pendidikan Islam. Masalah utamanya adalah masih kurangnya kesadaran peserta didik untuk mempelajari dan menggunakan bahasa Inggris sebagai bahasa asing mereka. hal ini masih dikarenakan bahasa inggris dianggap sebagai suatu pelajaran yang sulit dan persepsi sebagian mahasiswa di perguruan tinggi islam bahwa bahasa inggris adalah bahasa orang kafir. Selain dengan menggunakan cara tradisional, pengajaran bahasa inggris dapat menggunakan metode ceramah dalam mengajarkan bahasa Inggris. Ada cara-cara lain yang memungkinkan peserta didik lebih tertarik kepada bahasa Inggris, misalnya sering menggunakan metode permainan, 
mengadakan music club, menyanyi bersama dengan lagu-lagu yang menggunakan bahasa Inggris, ataupun menonton film yang menggunakan bahasa Inggris setelah itu membahas film itu, baik dari segi cerita, karakter, budaya maupun hal-hal lain yang berhubungan dengan film itu dengan menggunakan bahasa Inggris bagi mahasiswa di perguruan tinggi islam.

Di Indonesia, bahasa Inggris dilihat sebagai media yang penting untuk mengembangkan dan memacu pertumbuhan ekonomi, sehingga pengajaran bahasa Inggris diharapkan bisa membantu tercapainya tujuan tersebut (Alisjahbana, 1990). Dalam bidang pengajaran bahasa Inggris, penekanan diberikan untuk kebutuhan memahami naskah dan dokumen yang berhubungan dengan perkembangan teknologi (Alwasilah, 2005). Sementara itu, Rudiyanto (1988) mencatat banyaknya ilmuwan di Indonesia yang belajar di luar negeri untuk kepentingan pengembangan ipteks. Mereka yang belajar di luar negeri membutuhkan sertifikat TOEFL (Test of English as a Foreign Language)yang menjadi persyaratan (Kareviati, 2004). Dewasa ini, bahasa Inggris di Indonesia semakin dibutuhkan dalam berbagai bidang seperti diplomasi, birokrasi, perdagangan, dan pariwisata, yang membutuhkan kontak langsung dengan pihak asing (Alisjahbana, 1990). Di Indonesia, pengajaran bahasa Inggris di institusi pendidikan ditekankan pada penggunaan bahasa Inggris untuk akademis (Bire, 1993). Dijelaskan lebih lanjut bahwa tradisi pengajaran bahasa Inggris di Indonesia menekankan mahasiswa untuk menghafal kosakata dan menerjemahan. Tidak mengherankan pengajaran bahasa Inggris di negara kita lebih pada membaca dan menerjemahkan (Rudiyanto, 1988). Penekanan pada tata bahasa dan keterampilan membaca dapat mempermudah pelaksanaan ujian karena aspek-aspek bahasa yang ditanyakan lebih mudah dinilai (Harmer, 2001).

\section{Urgensi Bahasa Inggris sebagai Mata Kuliah ESP di Perguruan Tinggi Islam}

Pada abad ini, Bahasa Inggris menjadi bahasa global dunia. Di dunia manapun seseorang berada, selama menggunakan Bahasa Inggris maka komunikasi akan dipahami oleh lawan bicaranya. Seperti contoh di Bali, semua pengunjung Internasional menggunakan Bahasa Inggris sebagai bahasa utama dalam berkomunikasi dengan masyarakat lokal. Begitu juga, apabila berkunjung ke negara lain maka bahasa yang digunakan untuk 
berkomunikasi adalah bahasa global, Bahasa Inggris. Bahasa Inggris tidak hanya menjadi bahasa internasional yang hanya digunakan ketika terjadi komunikasi antara dua orang yang berasal dari dua negara atau lebih6. Seperti contoh, Bahasa Arab, yang merupakan bahasa internasional, digunakan ketika orang dari negara yang berbeda bertemu dengan orang Arab. Begitu pula Bahasa Jepang, digunakan hanya saat seseorang berada di lingkungan yang orang, tradisi ataupun bisnisnya didominasi oleh orang yang berbahasa Jepang. Hal ini berbeda dengan Bahasa Inggris yang penggunaanya menyebar di seluruh dunia sekalipun tidak ada hubungannya sama sekali dengan negara-negara yang berbahasa Inggris. Dengan kata lain, Bahasa Inggris adalah lingua franca dunia yang menjadi alat komunikasi antara orang-orang yang berbeda negara.

Sebagai bahasa global, tentu penggunaannya bukan hanya sebagai media berkomunikasi secara verbal, melainkan juga dalam berbagai segi kehidupan seperti bahasa pemprograman komputer, buku panduan produk, sumber-sumber pendidikan, ekonomi dan lain- lain. Bahkan, dalam kurikulum pendidikan, Bahasa Inggris tidak hanya diajarkan di negara yang berbahasa Inggris sebagai bahasa utama, tetapi hampir di semua negara di seluruh dunia. Dengan penggunaan yang sangat masif hampir di seluruh aspek kehidupan, maka mempelajari Bahasa Inggris menjadi kebutuhan yang tidak bisadipungkiri.

"All of the problem that confront the Muslim world today the educational problem is the most challenging. The future of the Muslim world will depend upon the way it responds to this challenge",

artinya: Dari sekian banyak permasalahan yang merupakan tantangan terhadap dunia Islam dewasa ini, maka masalah pendidikan merupakan masalah yang paling menantang. Masa depan dunia Islam tergantung kepada cara dunia Islam menjawab dan memecahkan tantangan ini. Pernyataan Khursid Ahmad diatas menunjukkan bahwa pendidikan merupakan kebutuhan penting bagi setiap manusia, masyarakat, maupun bangsa, maka pendidikan harus selalu ditumbuhkembangkan secara sistematis dan visioner. Berangkat dari kerangka ini, maka upaya pendidikan yang dilakukan suatu bangsa selalu memiliki hubungan yang signifikan dengan rekayasa bangsa tersebut di masa mendatang. Bahasa Inggris untuk bekal di dunia agar mampu bersaing dan dapat menghadapi era globalisasi. 
Pada zaman globalisasi sekarang, kita tidak hanya dituntut untuk mempelajari pendidikan yang bersifat ukhrawi melainkan juga duniawi. Karena kita tidak hidup sendirian tapi bermasyarakat, kita tidak hidup di Negara yang hanya satu-satunya di dunia, melainkan bertetangga. Dan dalam bertetangga pasti ada hubungan, dalam hubungan pasti ada komunikasi dan dalam komunikasi pasti ada bahasa. Bahasa apakah yang akan kita gunakan dalam berkomunikasi dengan Negara lain? atau mempelajari ilmu atau bukubuku dari Negara lain yang tidak sebahasa dengan kita? Tentunya dunia sudah menetapkan satu bahasa internasional pemersatu antar negara untuk melakukan komunikasi, yaitu bahasa inggris. Sebenarnya, pembelajaran bahasa Inggris di perguruan tinggi 2 SKS atau berapa pun mengundang pertanyaan mendasar. Apakah pembelajaran ini ditujukan untuk kepentingan mahasiswa selama kuliah ataukah kepentingan sarjana (lulusan) di dunia kerja? Pertanyaan ini berkaitan dengan kapan bahasa Inggris akan diajarkan.

Jika untuk kepentingan mahasiswa selama kuliah, kemampuan berbahasa Inggris seharusnya menjadi syarat bagi calon mahasiswa untuk menempuh kuliah. Sebab selama kuliah, mahasiswa berhadapan dengan literaturliteratur berbahasa Inggris, berkesempatan mengikuti program pertukaran mahasiswa dan kegiatankegiatan internasional yang mensyaratkan kemampuan berbahasa Inggris. Artinya, mahasiswa yang tidak dapat berbahasa Inggris tentu tidak akan mampu mengikuti program dan kegiatan itu dengan optimal. Namun, pada kenyataannya, perkuliahan S-1, S-2 dan bahkan S-3 memakai banyak literatur berbahasa Indonesia. Alasannya bukan karena materi perkuliahan telah tercukupi dengan literatur-literatur berbahasa Indonesia, melainkan karena sebagian (besar) dosen tidak mampu membaca literatur berbahasa Inggris dengan baik. Sehingga, syarat kemampuan berbahasa Inggris bagi calon mahasiswa pun cenderung dianggap sebagai formalitas belaka.

Untuk kepentingan kuliah, bahasa Inggris semestinya diajarkan sebelum calon mahasiswa mengikuti kuliah, atau setidaknya pada semester-semester awal perkuliahan. Lain halnya, untuk kepentingan lulusan di jagat kerja, bahasa Inggris bisa diajarkan pada semester-semester akhir. Namun, bila ditujukan untuk dua kepentingan itu, pembelajaran bahasa Inggris sepatutnya dilaksanakan sejak semester awal sampai akhir. Pada akhir pembelajaran 
bahasa Inggris, kemampuan mahasiswa dites, misalnya dengan TOEFL atau IELTS. Lantas, mahasiswa mendapat sertifikat yang berisikan skor tesnya. Skor kelulusan ditentukan oleh perguruan tinggi. Perlu diingat bahwa sertifikat tes bahasa Inggris ini mempunyai masa berlaku yang terbatas, lazimnya dua tahun, seperti yang ditetapkan oleh lembaga-lembaga penyelenggara program beasiswa. Psikolinguistik menjelaskan bahwa kemampuan berbahasa asing pada seseorang akan menurun bila bahasa tersebut tidak atau jarang digunakan. Karenanya, kemampuan bahasa Inggris mahasiswa sepatutnya dites setiap dua tahun.

Kemampuan dasar berbahasa Inggris mencakup membaca (reading), mendengar (listening), menulis (writing), dan berbicara (speaking). Keempat kemampuan dasar ini merupakan keterampilan (skill) dan berada pada ranah psikomotor. Maka, pengajaran bahasa Inggris seharusnya menekankan pada keterampilan reading, listening, writing dan speaking, bukan pada pengetahuan tentang bahasa Inggris. Sampai sekarang, pembelajaran bahasa Inggris di SD hingga perguruan tinggi galibnya menekankan pada pengetahuan tentang bahasa Inggris. Evaluasinya terfokus pada pengetahuan, bukan keterampilan berbahasa. Titik tekan dan fokus ini menjadi salah satu penyebab kegagalan pembelajaran bahasa Inggris di Nusantara. Kritik terhadapnya sudah lama sekali mengemuka, tetapi lagi-lagi solusinya tidak efektif.

Dilihat dari fungsinya di dalam kurikulum, ESP di perguruan tinggi Islam hanya diajarkan sebagai salah satu materi kuliah dasar umum (MKDU) saja, sehingga baik pimpinan perguruan tinggi, dosen dan mahasiswa menganggap bahwa bahasa Inggris hanya sebagai salah satu mata kuliah yang tidak begitu penting dan hanya diajarkan sebagai salah satu syarat dalam pemenuhan kurikulum nasional. Dilihat dari manfaatnya, pengajaran ESP di perguruan tinggi tidak begitu terlihat, Ini ditandai dengan kurangnya penguasaan materi perkuliahan bahasa Inggris yang mengacu kepada unsur-unsur keislaman. Mahasiswa hanya menangkap materi perkuliahan hanya sebatas penguasaan kosakata gramatika bahasa Inggris secara umum saja. Padahal dilihat dari tekanan esensinya, pengajaran bahasa Inggris di perguruan tinggi Islam diarahkan kepada kemampuan mahasiswa dalam membaca, menulis, dan menyimak berbagai hal yang berkaitan dengan faktor keislaman. 


\section{Persepsi tentang Mata Kuliah Bahasa Inggris di Perguruan Tinggi Islam}

Dalam pelaksanaannya, mata kuliah bahasa Inggris ini cenderung ditafsirkan dan dilaksanakan secara berbeda - beda. Ada yang menganggap nya sebagai mata kuliah yang berisi materi bahasa Inggris umum yang berisi pengetahuan dasar bahasa Inggris umum dengan berbagai unsur dan keterampilannya. Sebaliknya, ada pula yang berpendapat bahwa mata kuliah ini adalah mata kuliah untuk tujuan khusus yang disesuaikan dengan bidang studi mahasiswa, sekalipun dalam pelaksanaannya cenderung belum mencerminkan esensinya sebagai mata kuliah untuk tujuan tertentu. Di dalam pelaksanaannya, walaupun sudah dianggap sebagai mata kuliah ESP, mata kuliah ini belum mencerminkan implementasi dari teori ESP yang seharusnya. Mata kuliah ini mengalami berbagai masalah dari banyak sisi, baik perancangannya, pelaksanaannya, maupun evaluasinya.

Bidang pengajaran bahasa Inggris dengan tujuan tertentu atau lebih dikenal dengan English for Specific Purpose (ESP) merupakan bidang pengajaran bahasa Inggris yang tergolong baru. Perkembangan ESP di perguruan tinggi baik itu perguruan tinggi umum maupun perguruan tinggi agama di Indonesia masih samar-samar. Ini terlihat pada penggunaan nama ESP itu sendiri sebagai nama mata kuliah yang diajarkan. Di dalam kurikulum perguruan tinggi, ESP hanya bertajuk sebagai mata kuliah bahasa Inggris (BI) saja. Di dalam pelaksanaannya, bahasa Inggris diajarkan sesuai dengan alokasi sistem kredit semester (SKS) yang diterapkan oleh masing-masing perguruan tinggi. Perguruan tinggi umum yang menganggap bahasa Inggris begitu penting peranannya mengalokasikan 4-6 sks sedangkan perguruan tinggi umum yang menganggap bahasa Inggris hanya sebagai mata kuliah dasar umum hanya mengalokasikan sekitar 2- 4 sks saja sedangkan di perguruan tinggi agama, bobot sks bahasa Inggris yang dialokasikan berkisar antara 2 - 4 sks, bahkan ada yang hanya 2 sks saja.

English for Specific Purpose (ESP) adalah pengajaran bahasa Inggris untuk tujuan-tujuan tertentu. Hutchinson dan Waters (1987: 19) mendefinisikan "ESP is an approach to language teaching in which all decisions as to content and method are based on the learner's reason for learning". Dari pendapat di atas dapat disimpulkan bahwa ESP adalah suatu pendekatan dalam pengajaran yang mengedepankan kebutuhan atau alasan si pembelajar belajar bahasa Inggris. ESP 
digambarkan sebagai pengajaran bahasa Inggris untuk tujuan tujuan tertentu yang dapat dikhususkan. Namun ahli lainnya menggambarkan bahwa ESP adalah pengajaran bahasa Inggris yang dilaksanakan pada studi studi akademik atau pengajaran bahasa Inggris untuk tujuan pekerjaan tertentu atau untuk tujuan profesi profesi tertentu.

Materi ajar memegang peranan penting dalam upaya pencapaian suatu tujuan pengajaran. Begitu besarnya peran materi ajar sehingga Tomlinson (1998) menyatakan bahwa bidang apa pun yang diajar dalam kerangka pengajaran yang berpusat pada pelajar, materi ajar merupakan yang terpenting. Selain materi ajar, tujuan pembelajaran merupakan arah yang hendak dituju dari rangkaian aktivitas yang dilakukan dalam proses pembelajaran. Pada dasarnya esensi tujuan pembelajaran adalah tercapainya perubahan perilaku atau kemampuan siswa setelah mengikuti kegiatan pembelajaran dan dirumuskan dalam bentuk deskripsi yang spesifik, tujuan pembelajaran adalah merupakan arah yang hendak dituju dari rangkaian aktivitas yang dilakukan dalam proses pembelajaran.

Pada dasarnya esensi tujuan pembelajaran adalah tercapainya perubahan perilaku atau kemampuan siswa setelah mengikuti kegiatan pembelajaran dan dirumuskan dalam bentuk deskripsi yang spesifik. Berikutnya yang tidak kalah penting dalam pembelajaran adalah pendekatan pembelajaran. Jack C. Richard mengutip pendapat Anthony mengatakan pendekatan dalam pembelajaran bahasa, yakni serangkaian asumsi yang bersifat aksiomatis tentang sifat dan hakikat bahasa sedangkan metode merupakan rencana menyeluruh mengenai penyajian materi pengajaran bahasa secara teratur dan didasarkan atas suatu pendekatan yang dipilih. Selain itu, Hamalik dalam Arsyad (2007:15) mengemukakan bahwa penggunaan media pembelajaran dalam proses belejar mengajar dapat membangkitkan keinginan dan minat yang baik, membangkitkan motivasi dan rangsangan kegiatan belajar, dan bahkan membawa pengaruh-pengaruh psikologis terhadap siswa. Penggunaan media pembelajaran pada tahap orientasi pembelajaran akan sangat membantu keefektifan proses pembelajaran dan penyampaian pesan dan isi pelajaran pada saat itu. Terakhir di dalam komponen pembelajaran adalah evaluasi. Menurut Gagne (1979:82) setiap guru atau perancang pembelajaran pasti ingin mendapatkan kepastian bahwa kegiatan belajar mengajarnya selama kurun waktu 
tertentu memiliki nilai guna bagi proses pembelajaran. Setidaknya guru ingin mengetahui apakah rancangan pelajarannya berhasil dan mencapai tujuan pembelajaran.

Tujuan pembelajaran bahasa inggris dalam konteks ESP (English for Spesific Purpose) di perguruan tinggi Islam bertujuan agar mahasiswa mampu menggunakan bahasa Inggris baik secara tertulis maupun lisan dalam memahami bacaan dalam text-text berbahasa Inggris khusus jurusan di masing-masing fakultas. Tujuan pembelajaran tersebut sesuai dengan pembelajaran bahasa Inggris yang terbagi atas bahasa Inggris 1, bahasa inggris 2, dan ada juga bahasa Inggris 3. Secara khusus tujuan pembelajaran bahasa Inggris 1 adalah agar mahasiswa dapat memahami Tata Bahasa (Grammar) dasar bahasa Inggris dan kemampuan dasar membaca (pengajaran bahasa Inggris secara umum), tujuan yang mengacu kepada pengajaran ESP adalah mahasiswa diharapkan memiliki pengetahuan tentang struktur kalimat dalam bahasa Inggris, teknik-teknik pemahaman bacaan teks-teks yang ditulis dalam bahasa Inggris, serta mampu memahami makna kosa kata dalam konteks kajian Islam (pengajaran bahasa Ingris untuk tujuan tujuan khusus). Mahasiswa mampu memahami Grammar bahasa Inggris dan buku-buku serta jurnal-jurnal yang berhubungan dengan science dan technology. (ESP). Mahasiswa diharapkan memiliki keunggulan kompetitif dan komperatif sesuai dengan mutu nasional dan Internasional yang berbasis kompetensi, terutama dalam membangun dan mengembangkan kemampuan dan keterampilan bahasa Inggris baik lisan maupun tulisan yang mencakup: listening, speaking, reading, dan writing.

Tujuan Speaking and Listening mencakup kemampuan mahasiswa untuk memahami dan mengungkapkan informasi dalam komunikasi lisan, dan meliputi fonologi bahasa Inggris, penekanan kata dan kalimat, ritme dan intonasi, dan informasi yang disampaikan lewat sistem-sistem tersebut. Tujuan reading adalah mengembangkan kemampuan mahasiswa dalam memahami, mengartikan, merefleksikan, menanggapi dan menikmati teks-teks tulis. Sedangkan dalam dimensi writing, tujuannya adalah untuk mengenalkan bahasa Inggris tertulis pada mahasiswa, termasuk kemampuan menyusun dan menyajikan berbagai jenis teks. Tujuan ini juga meliputi perkembangan sistem bunyi-simbol dalam bahasa Inggris, kosakata, dan tata bahasa. Keempat 
keterampilan berbahasa yang ada dalam pembelajaran bahasa Inggris di atas lebih ditekankan pada reading competency guna memahami teks-teks keagamaan, hukum, ekonomi, sosial, politik, atau disiplin ilmu lain sesuai dengan jurusan masing - masing. Mengembangkan kemampuan menyerap kosakata bahasa Inggris serta mengembangkan pemahaman teks bacaan.

Dalam kegiatan pembelajaran, dosen dalam menyampaikan proses pembelajaran menggunakan pendekat an, metode, dan teknik. Dengan adanya pendekatan, metode, dan teknik kegiatan pembelajaran akan dapat berwarna/ bervariasi dan kegiatan tersebut juga dapat terlaksana dengan baik. Menurut Subana dan sunarti (1998:19) Istilah pendekatan (approach) sering dikaitkan dengan metode (method) dan teknik (technique). Semua istilah itu merupakan tiga aspek yang saling berkaitan. Pendekatan digunakan untuk merujuk pada rancang bangun silabus (syllabus design) dan pendekatan bersifat filosofis/aksioma, sedangkan metode merupakan cara melaksanakan pembelajaran. Lain halnya dengan teknik yang mengandung pengertian berbagai cara dan alat yang digunakan dosen dalam kelas. Dengan demikian, teknik adalah daya upaya, usaha, cara yang digunakan dosen dalam mencapai tujuan langsung dalam pelaksanaan pengajaran.

Apabila merujuk kepada pengertian di atas, sudah tentu dosen memahami bagaimana menggunakan dan menerapkan metode pembelajaran sesuai dengan materi ajar yang digunakan. Materi ajar yang digunakan akan dapat tuntas dan dapat dipahami oleh mahasiswa apabila dosen dapat menerapkan metode pembelajaran secara tepat dan efektif. Berdasarkan hasil observasi dalam kegiatan pembelajaran bahasa Inggris di kelas terlihat bahwa sebagian besar dosen sudah menggunakan berbagai metode pembelajaran yang berpusat kepada siswa (student center). Hal ini terlihat dari penggunaan metode pembelajaran role playing, active learning, discussion, presentation, dan lain-lain. Selain menggunakan metode pembelajaran yang berpusat kepada peserta didik (student center), pembelajaran bahasa Inggris pada hampir seluruh perguruan tinggi islam sebagian besar menggunakan metode pembelajaran yang berpusat kepada guru (dosen). Hal ini terlihat dengan masih secara dominannya dosen menggunakan metode ceramah dalam menyampaikan materi perkuliahan. Selain itu juga, terlihat dosen masih menggunakan 
metode penugasan, latihan, audiolingual, dan lain sebagainya.

\section{E. Kesimpulan dan Saran}

Melihat fenomena bahwa pembahasan isu-isu keagamaan pada saat ini banyak menggunakan Bahasa Inggris, sudah menjadi kemestian bahwa mahasiswa yang berlatar pendidikan keagamaan perlu menguasai Bahasa Inggris sebagai alat untuk mengetahui isu agama kekinian serta untuk menerbitkan hasil pemikiran dan penelitiannya. Dalam sebuah proses pembelajaran, perspektif dari setiap individu sangat berperan dalam proses pencapaian tujuan dari pembelajaran yang dilakukan. Perspektif akan berpengaruh terhadap perilaku, sikap, respon dan motivasi yang dimiliki. Dengan kata lain, perspektif yang positif terhadap

sesuatu akan membuat seseorang memiliki motivasi untuk mewujudkan sesuatu tersebut. Seperti contoh, ketika seseorang memiliki perspektif yang positif terhadap Bahasa Inggris, maka mereka akan berupaya untuk mempelajari dan menguasainya dengan mengikuti kegiatan pembelajaran di kelas dengan baik atau bahkan akan mencari kelas atau aktifitas tambahan untuk meningkatkan kemampuannya.
Begitu pula sebaliknya, ketika seseorang bersikap apatis terhadap Bahasa Inggris, maka sikap malas untuk mengikuti kegiatan pembelajaran akan timbul. Dampak yang akan timbul kemudian ialah bahwa mahasiswa tersebut tidak akan berpartisipasi secara maksimal didalam kelas untuk mengikuti mata kuliah bahasa inggris.

\section{F. Daftar Pustaka}

Abbas, Saleh, Pembelajaran Bahasa Indonesia yang Efektif di Sekolah Dasar Jakarta: Depdiknas, 2006

Alisjahbana, Sutan Takdir. (1990). The teaching of English in Indonesia. Dalam James Britton, Roberts E.Syeffer and Ken Watson (Eds.). Teaching and Learning English Worldwide. hal: 315- 327. Multilingual Matters: Philadelphia.

Alwasilah, A. Chaedar. (2005). "Ada Apa dengan IImu Bahasa?". Pikiran Rakyat (12 Maret 2005).

Arsyad, Azhar. (2008). Media Pembelajaran, Jakarta: PT Raja Grafindo Persada.

David Crystal, English as a global language. (Cambridge: Cambridge University Press, 1997). Depdiknas, (2003) Undang-Undang No. 20 tahun 2003 tentang Sistem Pendidikan Nasional, Jakarta: Depdiknas 
Gagne, Robert. (1979). Principle of Instructional Design, Hoit: Rinehart and Winton, 1979.

Hutchinson T. \& A. Waters (1987) English for Specific Purposes: A learningCentred Approach, Cambridge: Cambridge university Press.

Nunan, David. (2003). Practical English Language Teaching. New York: McGraw-Hill. 2003.

Richards, Jack C \& Theodore S. Rodgers, Approaches and Methods in Language Teaching,
UK: Cambridge University Press, 2000

Spradley, James P. (1997). Metode Etnografi, Yogyakarta: Tiara Wacana.

Tomlinson, B. (1998). Materials Development in Language teaching, Cambridge: Cambridge University Press.

Zuliati Rohmah, "English as global Language", Journal Bahasa dan Seni, (Universitas Negeri Malang, 2015). 